\title{
Wheel wear during the operation of rail vehicles. Causes and effects
}

\author{
Zużycie koła podczas eksploatacji pojazdów szynowych. \\ Przyczyny i skutki
}

\begin{abstract}
The article presents the issues related to the wear of the outer outline of monoblock wheel rims in rail vehicles. The most often causes of wheel wear during commercial operation of rail vehicles are presented over the many decades of experiences gathered by European boards. The effects of rail vehicle wheels wear and countermeasures against wear are presented.
\end{abstract}

$W$ artykule przedstawiono problematykę zwiqzana ze zużyciem zarysu zewnętrznego wieńców kót monoblokowych w pojazdach szynowych. Przedstawiono najczęstsze przyczyny zużycia kót podczas eksploatacji komercyjnej pojazdów szynowych na przestrzeni wielu doświadczeń zebranych podczas wielu dziesiatków lat przez zarzqdy europejskie. Zaprezentowano skutki zużycia kót pojazdów szynowych oraz środki zaradcze, przeciwdziałajace zużyciu.

\section{INTRODUCTION}

Wear in the wheel-rail system is one of the most significant problems in modern railways. This study is a further continuation of the significant problems that occur in urban, suburban, regional and longdistance passenger rail transport and freight rail transport $[4 \div 10]$. Its importance has not diminished at all, but increased with the development of rail vehicles in two main directions: the increase in speed to $350 \mathrm{~km} / \mathrm{h}$ (long-distance multiple units) and the increase in the wheelset load per track on regular lines to $22.5 \mathrm{t}$ and selected 25t $(245 \mathrm{kN})-$ e.g. Kiruna-Narvik (SwedenNorway), and on some selected, separated railway lines $30 \mathrm{t}(294 \mathrm{kN}$, heavy freight, iron ore transport) in the countries of the European Union The wheel-rail system should be considered as the most loaded construction and operational node in modern railway technology. The wear of the rolling surface of the outer outline of the monoblock wheel rims is a function of the vertical pressure of the wheel on the rail $\mathbf{Q}_{\mathbf{r z}}$ (wear of the rolling surface) and the longitudinal friction forces during travel and the forces occurring at start-up and braking, but the flange wear is a function of the acting lateral forces $\mathbf{Y}$. According to the detailed study work the problem is more complex from the point of view of modern technology. The more complex a vehicle is (e.g. a multiple unit set for regional or long-distance traffic), the more important issue of wheel wear becomes. The user/operator is not only interested in relatively low wear of the individual wheels, but also their even wear (as far as possible) not only in one running gear, but in the whole vehicle.

\section{WSTĘP}

Zużycie w układzie koło-szyna jest jednym z najistotniejszych problemów we współczesnym kolejnictwie. Niniejsze opracowanie jest dalszą kontynuacją istotnych problemów, które występują w transporcie kolejowym osobowym miejskim, podmiejskim, regionalnym i dalekobieżnym osobowym oraz transporcie kolejowym ładunków $[4 \div 10]$. Jego znaczenie wcale nie zmalało, a wzrosło wraz z rozwojem pojazdów szynowych w dwóch zasadniczych kierunkach: wzrost prędkości do $350 \mathrm{~km} / \mathrm{h}$ (zespoły trakcyjne dalekobieżne) oraz wzrost nacisku zestawu kołowego na tor na liniach regularnych do 22,5 t oraz wybranych $25 \mathrm{t}$ (245kN)-np. Kiruna-Narvik (Szwecja-Norwegia), a na niektórych wybranych, wydzielonych liniach kolejach 30t (294 kN, ciężkie przewozy towarowe, transport rudy żelaza) w krajach Unii Europejskiej. Układ koło-szyna należy uznać jako najbardziej obciążony węzeł konstrukcyjno-eksploatacyjny we współczesnej technice kolejowej. Zużycie powierzchni tocznej zarysu zewnętrznego wieńców kół monoblokowych jest funkcją nacisku pionowego koła na szynę $\mathbf{Q}_{\mathbf{r z}}$ (zużycie powierzchni tocznej) oraz sił wzdłużnych tarcia podczas jazdy oraz sił pojawiajacych się przy rozruchu i hamowaniu, natomiast zużycie obrzeża funkcją działających sił poprzecznych Y. Jak wynika ze szczegółowych prac studialnych problem jest bardziej złożony z punktu widzenia współczesnej techniki. Im bardziej złożony jest pojazd (np. wieloczłonowy zespół trakcyjny ruchu regionalnego lub dalekobieżnego), tym sprawa zużycia kół nabiera coraz większego znaczenia. Użytkownik/przewoźnik 
It should be taken into account that a traction unit has driving wheelsets and rolling wheelsets, situated differently in the construction of a traction unit, which leads to the conclusion that due to their location in the vehicle some wheelsets in relation to others are in a more favourable situation with respect to wear. The increasing requirements regarding the wheelset wear result from the current situation on the passenger and freight transport market, which direct to increased availability, reliability and maintenance-free operation or longer maintenance intervals. It seems, however, that all these requirements must lead to another development trend, namely the "monitoring" of the technical condition of the vehicle and the railway infrastructure using sensors installed on board ("online") of the rail vehicle, where the measured data are transmitted via radio to a central station, where the data are collected, classified, processed and evaluated from the point of view of operating safety. Thanks to a such procedure it is possible to make decision about repairing the vehicle in the moment when data indicate an imminent exceeding of permissible operating parameters ("on-time" repair).

\section{INFLUENCE OF INDIVIDUAL FACTORS ON WHEEL WEAR OF WHEELSET}

\subsection{Infuence of running gear construction on wheel} wear

Analysing the running gear of a rail vehicle, it should be considered the problem of the basic parameters influencing the wear of wheelsets. The basic factors which influence the wear of wheelsets due to the construction of bogie (the running gear) can be included:

- the ability to track curve negotiation with a radius of $\mathbf{R} \geq \mathbf{2 5 0} \mathbf{m}$ on main lines and siding tracks with a radius of $\mathbf{R} \geq \mathbf{1 5 0} \mathbf{~ m}$; this can be ensured constructionally by means of longitudinal clearances in the axlebox suspension (the so-called passive system of radial control of wheelset positioning in the track curves) and the use of radial control mechanism (the socalled active system of radial control of wheelset positioning in the track curves) as well as on the workshop tracks with radius $\mathbf{R}=\mathbf{1 0 0} \mathrm{m}$ (traction vehicles, passenger wagons) and with radii $\mathbf{R}=\mathbf{3 5} \mathbf{m}$ or $\mathbf{R}=\mathbf{7 5} \mathrm{m}$ (freight wagons),

- as far as possible, a small value of the resistance moment of the bogie relative to the body when the vehicle negotiates curves of the track; in the case of freight wagons, due to the fulfilment of the dynamic properties, this value must be specific (for freight wagons with a gross weight of $90 \mathbf{9 0 0} \mathbf{~ k g}$ the value should be approx. $45 \mathbf{~ k N m}$ ),

- small impact angles of the wheel on the rail head; in this case it depends on the bogie base; jest zainteresowany nie tylko relatywnie małym zużyciem pojedynczych kół, ale również ich równomiernym zużyciem (w miarę możliwości) nie tylko w jednym układzie biegowym, ale w całym pojeździe. Należy wziąć pod uwagę, że zespół trakcyjny posiada zestawy kołowe napędne oraz zestawy kołowe toczne, różnie usytuowane w konstrukcji zespołu trakcyjnego, skąd wynika wniosek, że ze względu na usytuowanie $\mathrm{w}$ pojeździe jedne zestawy w stosunku drugich są w bardziej korzystnej sytuacji ze względu na zużycie. Zwiększające się wymagania odnośnie zużycia kół zestawów kołowych, wynikają $\mathrm{z}$ obecnej sytuacji na rynku przewozowym osób i towarów, sprowadzające się do zwiększenia dyspozycyjności, niezawodności oraz bezobsługowości lub wydłużenia okresów między-naprawczych. Wydaje się jednak, że wszystkie te wymagania muszą prowadzić do innego trendu rozwojowego, a mianowicie „monitoringu” stanu technicznego pojazdu i infrastruktury kolejowej za pomoca czujników, zainstalowanych na pokładzie („online”) pojazdu szynowego, gdzie pomierzone dane sa przekazywane na drodze radiowej do centrali, gdzie dane są gromadzone, klasyfikowane, poddane obróbce oraz oceniane z punktu widzenia bezpieczeństwa eksploatacyjnego. Dzięki zastosowaniu takiej procedury można podjąć decyzję o przeprowadzeniu naprawy w chwili, kiedy dane wskazują na rychłe przekroczenie dopuszczalnych parametrów eksploatacyjnych (tzw. naprawa „on-time”).

\section{WPLYW POSZCZEGÓLNYCH CZYNNIKÓW NA ZUŻYCIE KÓE ZESTAWÓW KOLOWYCH}

\subsection{Wpływ konstrukcji układów biegowych na zużycie kól}

Analizując układ biegowy pojazdu szynowego, należy rozważyć problematykę podstawowych parametrów wpływających na zużycie kół zestawów kołowych. Do podstawowych czynników, które maja wpływ na zużycie kół zestawów kołowych z uwagi na konstrukcję wózka (układu biegowego) można zaliczyć:

- zdolność do wpisywania się w łuki toru o promieniu $\mathbf{R} \geq 250 \mathbf{m}$ na liniach szlakowych oraz na tory bocznicowe o promieniu $\mathbf{R} \geq \mathbf{1 5 0}$ m; konstrukcyjnie można to zapewnić przez zastosowanie luzów wzdłużnych w zawieszeniu przymaźnicznym (tzw. pasywny układ sterowania radialnego ustawiania sie zestawu kołowego w łukach toru) oraz zastosowanie mechanizmu sterowania radialnego (tzw. aktywny system układu sterowania radialnego ustawiania się zestawów kołowych w łukach toru) oraz na tory warsztatowe o promieniu $\mathbf{R}=\mathbf{1 0 0}$ m (pojazdy trakcyjne, wagony osobowe) oraz o promieniach $\mathbf{R}=\mathbf{3 5} \mathbf{m}$ lub $\mathbf{R}=\mathbf{7 5} \mathrm{m}$ (wagony towarowe), 
- the smaller bogie base is the impact angles are smaller, and with the increase of the bogie base the impact angles are larger; it should be taken into account that the bogie base in some cases is a result of standardization works, e.g. $1800 \mathrm{~mm}$ for the family of freight bogies of Y25 (UIC 510-1 leaflet [16]) and $2600 \mathrm{~mm}$ (UIC 515-0 leaflet [18]) for the running gears of passenger wagons; the base of driving bogie in case of traction vehicles is limited by the size of a drive transmission of engine+gearbox, whereas in case of the carrying bogies of passenger wagons, the electromagnetic brake may be such a boundary condition, especially when the longitudinal dimension of the equalizer is taken into account; it should also be taken into account that railway vehicle constructors aim at a compact construction of the bogie, because it is a favourable factor for the possible installation of other devices, e.g. pneumatic brake systems,

- use of a disc brake instead of a block brake; then the rolling surface of the wheel is significantly relieved; examples of such running gears are the following selected running gears of the design of the Śieć Badawcza Lukasiewicz - IPS ,TABOR”:

$\Rightarrow$ bogies 11ANa, 11ANc (for passenger wagons for maximum speed of $\mathbf{2 0 0} \mathbf{~} \mathbf{m} / \mathbf{h}$ and $\mathbf{2 5 0}$ $\mathbf{k m} / \mathbf{h}$ respectively),

$\Rightarrow$ bogie 5TN and 5TN/1 (for freight wagons e.g. $424 \mathrm{~S}$ with sliding walls for maximum speed of $160 \mathrm{~km} / \mathrm{h}$ ),

$\Rightarrow$ bogie $33 \mathrm{MN}$ for broken stone ballast cleaner OT-84,

$\Rightarrow$ bogie 6TN and 6TN/1 for bimodal transport (adapted for maximum speed of $\mathbf{1 6 0} \mathbf{~ k m} / \mathbf{h}$ ),

$\Rightarrow$ bogie for 111E locomotive (brake discs mounted on both sides of the wheels); the advantage of this type of solution is elimination of friction wear and thermo-mechanical loading of the wheel rim and significant reduction in the emission of noise to the environment, both in relation to the grey iron (GG) brake-shoe inserts, inserts made of composite materials with the same characteristics as the grey iron (LL) inserts and composite (K-type) inserts with a high coefficient of friction,

- use of a device for wheel flange lubrication (traction bogies of locomotives and multiple traction units),

- use of an inter-bogie coupling between the traction bogies of locomotives,

- use of an anti-slip system operating during start-up and braking, especially in the traction vehicles (locomotives and multiple units) to
- w miarą możliwości mała wartość momentu oporowego wózka względem nadwozia, podczas wpisywania się pojazdu $\mathrm{w}$ łuki toru; w przypadku wagonów towarowych $\mathrm{z}$ uwagi na spełnienie własności dynamicznych wartość ta musi mieć charakter określony (w przypadku wagonów towarowych o masie brutto 90000 kg wartość ta powinna wynosić ok. 45 kNm),

- małe kąty nabiegania koła na główkę szyny; w tym przypadku zależy to od bazy wózka; im mniejsza baza wózka kąty nabiegania maleją, natomiast ze wzrostem bazy wózka kąty nabiegania rosną; należy uwzględnić, że baza wózka w niektórych przypadkach jest efektem prac standaryzacyjnych np. $\mathbf{1 8 0 0} \mathbf{~ m m}$ rodzina wózków wagonów towarowych Y25 (karta UIC 510-1[16]) oraz $2600 \mathrm{~mm}$ (karta UIC 515-0 [18]) dla układów biegowych wagonów osobowych; bazę wózka napędnego w przypadku pojazdów trakcyjnych limituje rozmiar układu przeniesienia napędu silnik+przekładnia, natomiast w przypadku wózków tocznych dla wagonów osobowych, takim warunkiem brzegowym może być hamulec elektromagnetyczny, zwłaszcza kiedy uwzględni się wymiar wzdłużny wahacza; należy również wziąć pod uwagę, że konstruktorzy pojazdów szynowych i tak dążą do kompaktowej zabudowy wózka, gdyż jest to czynnik sprzyjający do ewentualnej zabudowy innych urządzeń np. układu pneumatycznego hamulcowych,

- zastosowanie hamulca tarczowego, zamiast hamulca klockowego; wówczas odciążona jest w sposób znaczący powierzchnia toczna koła; przykładami takich układów biegowych moga następujące, wybrane układy biegowe konstrukcji Sieci Badawczej Lukasiewicz IPS „TABOR":

$\Rightarrow$ wózki $11 \mathrm{ANa}, 11 \mathrm{ANc}$ (dla wagonów osobowych odpowiednio dla prędkości maksymalnej $200 \mathrm{~km} / \mathrm{h}$ oraz $250 \mathrm{~km} / \mathrm{h}$ ),

$\Rightarrow$ wózek $5 \mathrm{TN}$ i $5 \mathrm{TN} / 1$ (dla wagonów towarowych np. $424 \mathrm{~S}$ z rozsuwanymi ścianami do prędkości maksymalnej $160 \mathrm{~km} / \mathrm{h}$ ),

$\Rightarrow$ wózek $33 \mathrm{MN}$ dla oczyszczarki tłucznia OT84 ,

$\Rightarrow$ wózek $6 \mathrm{TN}$ i $6 \mathrm{TN} / 1$ do transportu bimodalnego (przystosowane do prędkości maksymalnej $160 \mathrm{~km} / \mathrm{h}$ ),

$\Rightarrow$ wózek dla lokomotywy $111 \mathrm{E}$ (tarcze hamulcowe zamontowane po obu stronach kół); zaletą tego rodzaju rozwiązania jest wyeliminowanie zużycia ciernego oraz obciążenia termo-mechanicznego wieńca koła oraz znaczące zmniejszenie emisji hałasu do środowiska naturalnego, zarówno w stosunku do 
prevent wheel slippage of individual wheel sets,

- systematic increase in the accuracy of making the running gear; the structure itself can't cause the wheelset to be skew placed on a straight track; such a situation may happen if the running gears are equipped with the suspension with a gap-free guiding of the wheelset,

- the amount of unit pressures „q" in the ellipse of the contact between the wheel and the rail; in this case, the decisive factor is the coefficient of friction,$\mu$ " between wheel and rail; as a result of the above, the decisive factors of wear of the outer surface of the wheel rim is the unit friction force , $\mu \times \mathbf{q}$." During operation, a dynamic factor occurs in the case of unit pressures, but the wheel-rail friction coefficient decreases with speed; thus, in the case of quasi-static riding there is a unit friction force,$\mu_{\text {MAX }} \mathbf{q} \mathbf{q}$, but in the case of operation , $\mu_{\text {DYNX }}\left(\mathbf{q}+\mathbf{q}_{\text {DYN }}\right)$ ".

In general, it can be concluded that all design measures limiting the values of forces in the wheel-rail interaction system contribute to lower wear of the rim of monoblock wheels.

Friction coefficient $\mu$ in the wheel-rail system is the result of some compromise in the railway technology. In the case of a low value of the friction coefficient, a lower wear of wheel rim can actually be expected. However, a relatively high value of the friction coefficient is desirable during:

- start-up of traction vehicles, which requires increasing adhesion by using the devices for sanding,

- using the handbrake or parking brake, especially on the track gradient, in order to prevent its low efficiency, and consequently undesirable, automatic setting the rail vehicle in motion,

- braking of the rail vehicle and

- reduces the safety while riding of the vehicle, especially in quasi-static conditions.

The value of the friction coefficient changeable in time and depends on many different factors. An average value of $\boldsymbol{\mu}=\mathbf{0 . 4}$ is often used in the calculations. In the case of lack of lubrication of rails and wheels and in atmospheric conditions with low humidity (so-called dry conditions), the value of the friction coefficient may even be $\boldsymbol{\mu}=\mathbf{0 . 5}$ [2]. In the case of using the wheel flange lubrication and rail grooves it is used the value of the coefficient value of $\boldsymbol{\mu}=\mathbf{0 . 1}$. But as the operational experience shows, the value of the friction coefficient may drop even below 0.1. It should be noticed that the friction coefficient is a statistical value between rails and wheels. In the case wstawek klocków hamulcowych z żeliwa szarego (GG), wstawek z materiałów kompozytowych o takiej samej charakterystyce jak wstawki z żeliwa szarego (LL) oraz wstawek kompozytowych (typu K) o dużym współczynniku tarcia,

- zastosowanie urządzenia do smarowania obrzeży kół (wózki trakcyjne lokomotyw i zespołów trakcyjnych),

- zastosowanie sprzęgu międzywózkowego pomiędzy wózkami trakcyjnymi lokomotyw,

- zastosowanie układu przeciwpoślizgowego, działającego podczas rozruchu i hamowania, zwłaszcza w pojazdach trakcyjnych (lokomotywy oraz zespoły trakcyjne), zapobiegającemu poślizgom kół poszczególnych zestawów kołowych,

- systematyczne zwiększenie dokładności wykonania układu biegowego; konstrukcja sama w sobie nie może wywoływać skośnego ustawienia zestawu kołowego na torze prostym; taka sytuacja może się zdarzyć jeżeli układy biegowe są wyposażone w zawieszenie z bezluzowym prowadzeniem zestawu kołowego,

- wielkość nacisków jednostkowych ,q” w elipsie styku pomiędzy kołem i szyną; w takim przypadku decydującym czynnikiem jest współczynnik tarcia,$\mu ”$ pomiędzy kołem, a szyną; wskutek powyższego do czynników decydującym o zużyciu powierzchni zewnętrznej wieńca koła jest jednostkowa siła tarcia , $\mu \times \mathbf{q .}$." W trakcie eksploatacji dochodzi czynnik dynamiczny w przypadku nacisków jednostkowych, ale współczynnik tarcia koło-szyna maleje wraz z prędkością tak więc w przypadku jazdy quasi-statycznej występuje jednostkowa siła tarcia,$\mu_{\text {MAXX }} \mathbf{q}$ ", natomiast podczas eksploatacji , $\mu_{\text {DYNX }}\left(\mathbf{q}+\mathbf{q}_{\mathrm{DYN}}\right) "$

Ogólnie można wysunąć wniosek, że wszystkie środki konstrukcyjne, ograniczające wartości sił w układzie oddziaływania koło-szyna, przyczyniają się do mniejszego zużycia wieńca kół monoblokowych.

Współczynnik tarcia $\mu \mathrm{w}$ układzie koło-szyna jest wynikiem pewnego kompromisu w technice kolejowej. W przypadku małej wartości współczynnika tarcia, rzeczywiście można spodziewać się mniejszego zużycia wieńca koła.

Jednak relatywnie duża wartość współczynnika tarcia jest pożądana podczas:

- rozruchu pojazdów trakcyjnych, co wymaga zwiększenia przyczepności poprzez zastosowanie urządzeń do piaskowania,

- wykorzystania hamulca ręcznego lub postojowego, zwłaszcza na pochyleniu toru, w celu 
of a rail, it is exposed to a large extent to the effects of the weather conditions, as a result of which oxide layers form and layers of dust and particulates are accumulate. The friction coefficient $\mu$ can be divided into four ranges of values:

$>\mathbf{0}<\boldsymbol{\mu} \leq \mathbf{0 , 1}$ - very humid conditions - range I,

$>0,1<\boldsymbol{\mu}<\mathbf{0 , 2 5}$ - humid conditions - range II,

$>0,25 \leq \boldsymbol{\mu} \leq \mathbf{0 , 4}$ - humid conditions - range III,

$>\boldsymbol{\mu}>\mathbf{0 , 4}$ - very dry conditions, low air humidity range IV.

The division into four value ranges makes it even visible that the friction coefficient has an influence not only on the wear of the wheel, but also on the operation of the vehicle. The functioning of the vehicle related to the value of the friction coefficient is influenced by such factors as riding safety in quasistatic and dynamic conditions as well as proper starting-up, braking and operation of the parking brake. A very high value of the coefficient, e.g. while riding in the quasi-static conditions and at starting - up of the rail vehicle has a negative impact on the life of the pressing connection between the seat of the axle of wheelset and the wheel hub (it reduces the safety factor of the pressing connection between the wheel hub and seat of axle).

\subsection{Influence of wheelset and wheel construction}

The factors influencing the wear on the part of the construction of the wheelset and wheels should include:

- difference of the rolling diameters of the wheels of the same wheelset; the smaller difference of wheelset diameters is, the lower value of the equivalent conicity (UIC 519 leaflet [19] and PN-EN 14363:2016 [15]) and the tendency of wheelset to slip is; with decreasing the difference of rolling radii, the vehicle becomes more and more symmetrical, the so-called the asymmetry angle of the entire construction of the vehicle " $\alpha$ " decreases, which entails a greater chance on a relatively even distribution of vertical pressure of the wheelsets during operation,

- outer outline of a wheel rim of a wheelset (wheel profile); the more it fits to the railhead profile, the less wear is; the selection of the outline of the outer rim of wheel has a long history, which will be described later in the text,

- value of the deviations in the shape of the rim of wheel, i.e. radial run-out of the rolling surface and internal rims (Fig. 1),

- roughness of the rolling surface of the wheel rim and flange, assessed using the parameters $\mathbf{R}_{\mathbf{a}}, \mathbf{R}_{\mathbf{Z}}$ and $\mathbf{R}_{\mathbf{t}}$; the smaller roughness of the wheels is (the greater the smoothness), the lower wear should be (Fig. 1),
- zapobieżenia jego niskiej sprawności, a w efekcie niepożądanemu, samoczynnemu wprawieniu w ruch pojazdu szynowego,

- hamowania pojazdu szynowego oraz

- zmniejsza bezpieczeństwo podczas jazdy pojazdu zwłaszcza w warunkach quasistatycznych.

Wartość współczynnika tarcia jest zmienna w czasie i zależy od wielu różnorodnych czynników. W obliczeniach przyjmuje się często wartość średnią, wynoszącą $\boldsymbol{\mu}=\mathbf{0 , 4}$. W wypadku braku smarowania szyn i kół i przy warunkach atmosferycznych o małej wilgotności (tzw. warunki suche) możliwa jest wartość współczynnika tarcia, wynosząca nawet $\boldsymbol{\mu}=\mathbf{0 , 5}$ [2]. W przypadku stosowania smarowania obrzeży kół oraz rowków szyn stosuje się wartość współczynnika wartość $\boldsymbol{\mu}=\mathbf{0 , 1}$. Ale jak wynika $\mathrm{z}$ doświadczeń eksploatacyjnych wartość współczynnika tarcia może spaść nawet poniżej 0,1. Należy zwrócić uwagę, że współczynnik tarcia jest wartością statystyczną pomiędzy szynami i kołami. W przypadku szyny, jest ona narażona w znacznym stopniu na działanie czynników atmosferycznych, w wyniku czego tworzą się warstwy tlenków oraz odkładają się warstwy kurzu i pyłu. Współczynnik tarcia $\mu$ można podzielić na cztery przedziały wartości:

$>\mathbf{0}<\boldsymbol{\mu} \leq \mathbf{0 , 1}$-warunki bardzo wilgotne- przedzial I,

$>\mathbf{0 , 1}<\boldsymbol{\mu}<\mathbf{0 , 2 5}$ - warunki wilgotne- przedzial II,

$>\mathbf{0 , 2 5} \leq \boldsymbol{\mu} \leq \mathbf{0 , 4}$-warunki suche- przedział III,

$>\boldsymbol{\mu}>\mathbf{0 , 4}$ - warunki bardzo suche, niska wilgotność powietrza- przedzial IV.

Podział na cztery przedziały wartości uwidacznia jeszcze bardziej, że współczynnik tarcia ma nie tylko wpływ na zużycie koła, ale również na funkcjonowanie pojazdu. Na funkcjonowanie pojazdu związane $\mathrm{z}$ wartością współczynnika tarcia, mają takie czynniki jak bezpieczeństwo jazdy w warunkach quasistatycznych i dynamicznych oraz właściwy rozruch, hamowanie i działanie hamulca postojowego. Bardzo duża wartość współczynnika np. podczas jazdy w warunkach quasi-statycznych oraz przy rozruchu pojazdu szynowego ma negatywny wpływ na trwałość połaczenia wtłaczanego pomiędzy podpiaściem osi zestawu kołowego i piastą koła (zmniejsza współczynnik bezpieczeństwa połączenia wtłaczanego pomiędzy piastą koła i podpiaściem osi).

\subsection{Wpływ konstrukcji zestawu kołowego i kon- strukcji koła}

Do czynników wpływających na zużycie ze strony konstrukcji zestawu kołowego oraz kół należy zaliczyć:

- różnicę średnic tocznych kół tego samego zestawu kołowego; im mniejsza różnica średnic zestawu kołowego tym mniejsza wartość stożkowatości ekwiwalentnej (karta 
- appropriate rigidity of the wheelset so that the width "A" between the inner rims of the wheels does not exceed $1360 \pm 3 \mathrm{~mm}$ under the maximum loaded vehicle (Fig. 1); in order to fulfill this condition, the same dimension from the dismounted wheelset from under the vehicle should be $\mathbf{1 3 6 0}^{+2}$, while this dimension is valid for wheelsets with the external bearings in accordance with UIC 510-2 leaflet [17] and PN-EN 13260+A1:2011[11]; it is necessary the appropriate rigidity of the axle made in accordance with the requirements of PN-EN 13261+A1:2011 [12] (especially in the middle part [8]) between them to meet this condition,

- use of appropriate types of steel for the wheel, resistant to wear, i.e. ER6, ER7 in the case of a disc brake and ER8 or ER9 in the case of a disc brake (steels according to PN-EN 13262:2011[13]); above materials are heattreated steels with compressive stresses in the rim of the wheel.

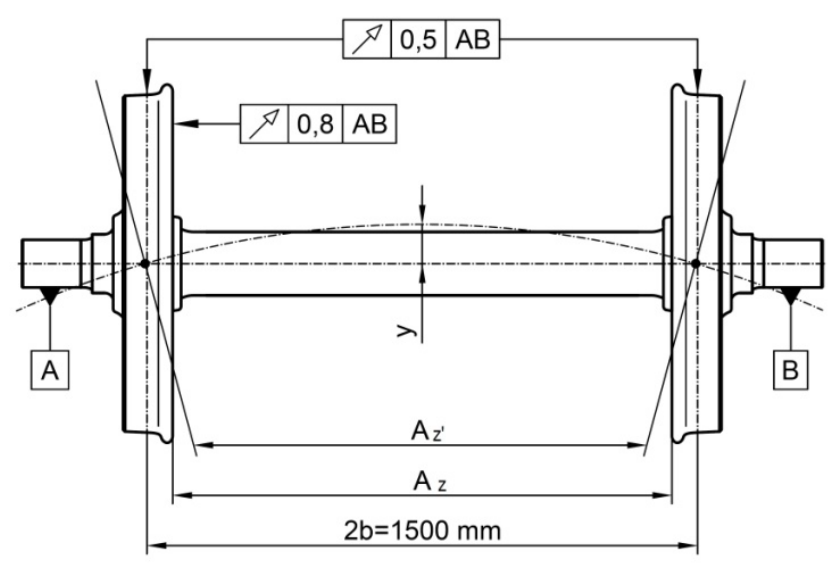

Rys.1.Wybrane wymiary konstrukcyjne i odchyłki kształtu zmontowanego zestawu kołowego

Fig.1. Selected construction dimensions and shape deviations of the assembled wheelset

Legenda:/Legend:

$\boldsymbol{A}, \boldsymbol{B}$ - bazy pomiarowe na czopach osi zestawu kołowego/ measurement bases on wheelset axle journals,

$\boldsymbol{A}_{Z}-$ rozstaw powierzchni wewnętrznych wieńców kót na zestawie kołowym $w$ stanie nowym oraz na zdemontowanym zestawie kotowym z pojazdu/distance of inner surfaces of wheel rims on the wheelset in new condition and on the disassembled wheelset from the vehicle,

$A_{Z}$ - rozstaw powierzchni wewnętrznych wienców kót, w zamontowanym na pojeździe załadowanym w stanie brutto; wymiar mierzony $w$ dolnej strefie, $w$ rejonie styku kót zestawu kołowego z szynami/ distance of inner surfaces of wheel rims mounted on the vehicle loaded in the gross condition; dimension measured in the lower zone, in the area of the wheelset's contact with the rails,

$\boldsymbol{2} \boldsymbol{b}$ - rozstaw kręów tocznych/ distance of the rolling treads.
- UIC 519 [19] oraz PN-EN 14363:2016 [15]) i skłonność kół zestawu do poślizgu; wraz ze zmniejszeniem się różnicy promieni tocznych, pojazd staje się coraz bardziej symetryczny, tzw.

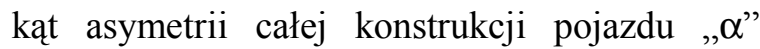
zmniejsza się, co pociagga za sobą większą szansę na w miarę równomierny rozkład nacisków pionowych zestawów kołowych w trakcie eksploatacji,

- zarys zewnętrzny wieńca koła zestawu kołowego (profil koła); im bardziej dopasowany do profilu główki szyny, tym zużycie jest mniejsze; dobór zarysu zewnętrznego wieńca koła ma swoją długą historię, która będzie opisana dalej w tekście,

- wartość odchyłek kształtu wieńca koła tzn.: bicie promieniowe powierzchni tocznej oraz wieńców wewnętrznych (rys.1),

- chropowatość powierzchni tocznej wieńca koła oraz obrzeża, oceniana przy pomocy parametrów $\mathbf{R}_{\mathbf{a}}, \mathbf{R}_{\mathbf{Z}}$ oraz $\mathbf{R}_{\mathbf{t}}$; im mniejsza chropowatość kół (im większa gładkość), tym zużycie powinno być mniejsze (rys.1),

- odpowiednią sztywność zestawu kołowego, tak aby szerokość „A” pomiędzy wewnętrznymi wieńcami kół nie przekraczała pod pojazdem maksymalnie załadowanym $\mathbf{1 3 6 0} \pm \mathbf{3} \mathrm{mm}$ (rys.1); aby ten warunek był spełniony ten sam wymiar $\mathrm{z}$ demontowanego zestawu kołowego spod pojazdu powinien wynosić $\mathbf{1 3 6 0}^{+2}$, przy czym wymiar niniejszy obowiązuje dla zewnętrznie ułożyskowanych zestawów kołowych zgodnie $\mathrm{z}$ karta UIC 510-2 [17] oraz PN-EN 13260+ A1:2011[11]; aby ten warunek był spełniony konieczna jest między innymi odpowiednia sztywność osi wykonanej zgodnie z wymaganiami PN-EN 13261+A1:2011 [12] (zwłaszcza w części środkowej[8]),

- zastosowanie odpowiednich gatunków stali na koło, odpornych na zużycie tzn. ER6, ER7 w przypadku hamulca klockowego oraz ER8 lub ER9 w przypadku hamulca tarczowego (stale wg PN-EN 13262: 2011[13]); ww. materiały są stalami ulepszanymi cieplnie $\mathrm{z}$ naprężeniami ściskającymi w wieńcu koła.

\subsection{Inne czynniki decydujące o zużyciu kół}

Do innych czynników, decydujących o zużyciu są takie, które są związane z torem kolejowym, a mianowicie:

$>$ trajektoria toru,

$>$ pochylenie profilu główki szyny [1:20 (profil DB), 1:40 (profil SNCF) oraz 1:30 (SJ koleje szwedzkie)],

$>$ jakość toru, a zwłaszcza wady toru, w postaci regularnych i nieregularnych nierówności pionowych i poprzecznych, 


\subsection{Other factors determining the wheel wear}

Other factors determining wear are those related to the railway track, namely:

$>$ track trajectory,

$>$ rail head profile inclination $[\mathbf{1 : 2 0}$ (DB profile), 1:40 (SNCF profile) and 1:30 (SJ Swedish railways)],

$>$ track quality, especially track defects in the form of regular and irregular vertical and lateral irregularities,

$>$ roughness of rails,

$>$ use of track moistening devices, especially on the curves with a small radius; this treatment reduces the friction coefficient (used on the SBB Swiss railways).

In turn, according to the study [1] the source of consumption are the general factors, which can include:

$>$ rail vehicle,

technical condition of the vehicle,

$>$ operation,

$>$ track position (routing), which is understood as the condition of the infrastructure (describing the required condition of the track with curves and cant),

$>$ technical condition of track (geometric deviations from the required track condition),

$>$ factors related to climate (ambient temperature, rainfall, frequency and intensity of rainfall, dust, sand, rail icing, etc.).

\subsection{Factors limiting wheel wear}

Factors affecting the permissible wear of the wheel (or the permissible range of wear) include such as:

$>$ minimum and maximum height of screw coupler and railway buffers,

$>$ deflection of primary suspension (freight wagons) or primary and secondary suspensions (passenger wagons) or primary, secondary and third suspensions (multiple units of high speed),

$>$ reference outline of the kinematic or static gauge,

$>$ wheel strength to vertical and lateral forces as well as friction forces,

$>$ wheel strength to the friction forces caused by the block brake, especially with the $\mathbf{L} \mathbf{L}$ and $\mathbf{L}$ inserts (instead of GG inserts according to UIC 832 leaflet [20]) and $\mathbf{K}$,

$>$ type of used brake (disc or block),

$>$ adjustment range of the brake block stroke adjuster and the value of the brake cylinder stroke,

$>$ the vehicle is not equipped with an anti-slip device,

$>$ riding safety in quasi-static and dynamic conditions,
> chropowatość szyn kolejowych,

$>$ stosowanie urządzeń nawilżających tor, zwłaszcza na łukach o małym promieniu; zabieg ten zmniejsza współczynnik tarcia (stosowany na kolejach szwajcarskich SBB).

$\mathrm{Z}$ kolei zgodnie zgodnie $\mathrm{z}$ opracowaniem [1] źródłem zużycia są ogólne czynniki, do których można zaliczyć:

$>$ pojazd szynowy,

$>$ stan techniczny pojazdu,

$>$ eksploatację,

$>$ położenie toru (trasowanie), przez które rozumie się stan infrastruktury (opisujące stan wymagany toru wraz z łukami i przechyłka$\mathrm{mi}$ ),

$>$ stan techniczny toru (odchyłki geometryczne od wymaganego stanu toru),

$>$ czynniki związane z klimatem (temperatura otoczenia, opady deszczu, częstotliwość i intensywność opadów deszczu, pył, piasek, oblodzenie szyn itd.)

\subsection{Czynniki ograniczające zużycie koła}

Do czynników mających wpływ na dopuszczalne zużycie koła (lub dopuszczalny zakres zużycia) należą między innymi:

> wysokość minimalna oraz maksymalna sprzęgu śrubowego i zderzaków kolejowych,

$>$ ugięcie usprężynowania I. stopnia (wagony towarowe) lub I. i II. stopnia (wagony osobowe) lub I., II. i III. stopnia (zespoły trakcyjne wysokich prędkości),

$>$ zarys odniesienia skrajni kinematycznej lub statycznej,

> wytrzymałość koła na działanie sił pionowych i poprzecznych oraz sił tarcia,

$>$ wytrzymałość koła na działanie sił tarcia, wywoływanych przez hamulec klockowy, zwłaszcza ze wstawką typu LL i L (zamiast wstawek GG wg karty UIC 832 [20]) oraz K,

$>$ rodzaj zastosowanego hamulca (tarczowy lub klockowy),

> zakres regulacji nastawiacza skoku klocków hamulcowych i wartość skoku cylindra hamulcowego,

> brak wyposażenia pojazdu w urządzenie antypoślizgowe,

$>$ bezpieczeństwo jazdy w warunkach quasistatycznych oraz dynamicznych,

$>$ bezpieczeństwo jazdy przez rozjazdy i skrzyżowania toru (wielkość parametru $\mathbf{q}_{\mathbf{R}}$ ),

$>$ ograniczenie do niezbędnego minimum wartości mas nieusprężynowanych, bezpośrednio oddziaływujących na tor,

> zdolność przejazdu przez hamulce torowe, które są zainstalowane u podnóża górek rozrządowych (np. wagony towarowe), 
$>$ riding safety across turnouts and track crossings (parameter value $\mathbf{q}_{\mathbf{R}}$ ),

$>$ limiting the values of the non-suspended masses directly affecting the track to the necessary minimum,

$>$ ability to riding over the track brakes that are installed at the foot of humps (e.g. freight wagons),

$>$ compatibility of the entrance step, steps of rail vehicle entrance door with the platform (multiple units of local, regional and highspeed transport and passenger wagons),

$>$ emission of consumption substances (including a worn wheel) to the environment,

$>$ the number of permissible disassemblies of worn wheels and installation of new wheels on the axle seat, which is associated with possible damage to surface of the axle seat and the necessity to turn the diameter to a lower dimension (the limitation here is the limit dimension of the minimum seat diameter),

$>$ emission of noise, vibrations and shocks to the natural environment (especially to residential buildings).

Paradoxically, the steel grades used for the railway rails are also a certain limitation in the scope of steel grades used for monoblock wheels. In the railway industry, the principle was adopted that the steel used for railway rails should have better strength properties and a higher hardness than steel used for railway wheels.

\section{Outer outline of the rim of monoblock wheels}

The selection of the outline of the outer rim of a wheel (wheel profile) has its 100th. history [3]. In the 1920s years a profile was used consisting of a straight cone with two inclinations of 1:20 respectively and on the outer part of 1:10 with a rounding radius of $\mathbf{1 5} \mathbf{~ m m}$ (between the rolling surface and the rim) and an inclination angle of $\mathbf{6 0}^{\circ}$.

In turn, in the 1930s it was found that the dynamic properties of wagons intended for higher speeds improve if the inclination is slightly gentler. Thus, the wheel profile with an inclination of 1:40 and 1:20 was used for these wagons (Fig. 2). Careful observation of the wear of passenger wagons, where the wheel profile with inclination of 1:40 and 1:20 was used, gave grounds to draw the conclusion that the increasing difference between the wheel diameters will not be evened out during further riding. Apart this the dynamic properties of the wagons deteriorated due to the indentation in the rolling surface. The expected mileage until the inspection at the repair shop turned out to be shorter than previously assumed. Besides that it was found that the wheelsets mounted on the vehicle had the tendency to one-sided impact, even on a straight track. As a result, the wheel profile was kompatybilność stopnia wejściowego, stopni drzwi wejściowych pojazdu szynowego $\mathrm{z}$ peronem (zespoły trakcyjne transportu lokalnego, regionalnego oraz wysokich prędkości oraz wagony osobowe),

$>$ emisja substancji zużycia (między innymi zużytego koła) do środowiska naturalnego,

$>$ ilość dopuszczalnych demontażów zużytych kół oraz montażu nowych kół na podpiaście osi, co wiąże się z możliwym uszkodzeniem powierzchni podpiaścia osi i konieczności przetoczenia średnicy na niższy wymiar (ograniczeniem jest tutaj wymiar kresowy minimalnej średnicy podpiaścia),

$>$ emisja hałasu drgań, wibracji i wstrząsów do środowiska naturalnego (zwłaszcza do budynków mieszkalnych).

Paradoksalnie użyte gatunki stali na szyny kolejowe są też pewnym ograniczeniem w zakresie gatunków użytych stali na koła monoblokowe. W kolejnictwie przyjęto zasadę, że stal użyta na szyny kolejowe powinna mieć lepsze własności wytrzymałościowe i wyższą twardość niż stale użyte na koła kolejowe.

\section{Zarys zewnętrzny wieńca kół monoblokowych}

Dobór zarysu zewnętrznego wieńca koła (profilu koła) ma swoją 100. historię [3]. W 20 latach XX wieku stosowano profil, składający się $\mathrm{z}$ prostego stożka o dwóch pochyleniach odpowiednio 1:20 oraz na zewnętrznej części 1:10, z promieniem zaokrąglenia $15 \mathrm{~mm}$ (pomiędzy powierzchnią toczną i obrzeżem) oraz kątem pochylenia obrzeża $\mathbf{6 0}^{\circ}$.

$\mathrm{Z}$ kolei w latach 30 . XX wieku stwierdzono, że właściwości dynamiczne wagonów przeznaczonych do wyższych prędkości polepszają się, jeśli pochylenie jest nieco łagodniejsze. W ten sposób doszło do zastosowania profilu koła o pochyleniu 1:40 oraz 1:20 dla tych wagonów (rys.2). Dokładna obserwacja zużycia wagonów osobowych, gdzie został zastosowany profil koła o pochyleniu 1:40 oraz 1:20 dała podstawy do wyciagnnięcia wniosku, że powiększająca się różnica pomiędzy średnicami kół nie będzie więcej wyrównana w trakcie dalszej jazdy. Oprócz tego pogarszały się własności dynamiczne wagonów z powodu wgłębienia na powierzchni tocznej. Przewidywany przebieg aż do przeprowadzenia przeglądu na warsztacie naprawczym okazał się krótszy, niż wcześniej zakładano. Poza tym stwierdzono, że zestawy kołowe zamontowane w pojeździe miały tendencje do jednostronnego nabiegania, nawet na torze prostym. W związku z tym dochodziło do przedwczesnych odtworzeń profilu kół (reprofilacji zarysu zewnętrznego wieńca koła).

Na początku lat 50. XX wieku doszło do wdrożenia profilu wg Heumanna i Lottera dla zespołów trakcyjnych (transport osobowy), który jest przedstawiony na rys.3. 
reconstructed prematurely (the outline of the outer rim of the wheel was re-profiled).

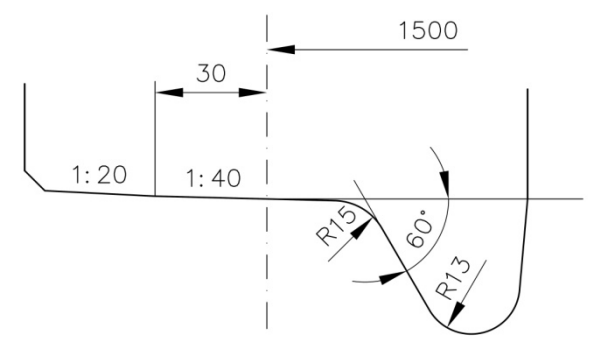

Rys.2. Zarys zewnętrzny wieńca koła z pochyleniem powierzchni tocznej 1:40 oraz 1:20 wg [3]

Fig.2. The outer outline of the wheel rim with a rolling surface inclination of 1:40 and 1:20 according to [3]

At the beginning of the $1950 \mathrm{~s}$, the profile according to Heumann and Lotter for traction units (passenger transport) was implemented, which is shown in Fig. 3. The important geometric changes that were introduced in this profile consisted in introducing:

$>$ two conical surfaces, i.e. without a radius (from the inside) and 1:10 (from the outside),

$>$ recess (transition) between the running surface and the flange with two radii $\mathbf{R}=\mathbf{1 5}$ $\mathbf{m m}$ and $\mathbf{R}=\mathbf{2 5} \mathbf{~ m m}$, and

$>$ the rim inclination angle $\gamma=\mathbf{7 0}^{\circ}$, instead of the previously used angle $\boldsymbol{\gamma}=\mathbf{6 0}^{\circ}{ }^{\circ}$

This was the first attempt to approach the use of such a profile, which is formed as a result of wear, but is still a profile matched to the wheel-rail friction pair. The introduction of the rim inclination angle from $\gamma=\mathbf{6 0}^{\circ}$ to $\gamma=\mathbf{7 0}^{\circ}$ changed in favor of the safety criterion against derailment in accordance with the dependencies:

$$
\begin{aligned}
& \frac{\mathrm{Y}}{\mathrm{Q}}=\frac{\operatorname{tg} \gamma-\mu}{1+\mu \cdot \operatorname{tg} \gamma}=\frac{\operatorname{tg} 60^{0}-0,36}{1+0,36 \cdot \operatorname{tg} 60^{\circ}}=0,84 \\
& \frac{\mathrm{Y}}{\mathrm{Q}}=\frac{\operatorname{tg} \gamma-\mu}{1+\mu \cdot \operatorname{tg} \gamma}=\frac{\operatorname{tg} 70^{\circ}-0,36}{1+0,36 \cdot \operatorname{tg} 70^{\circ}}=1,20
\end{aligned}
$$

where:

Y,Q- odpowiednio siła poprzeczna oraz siła pionowa / lateral force and vertical force, respectively,

$\mu$ - współczynnik tarcia między obrzeżem koła i główką szyny/ friction coefficient between the flange of the wheel and the rail head.

The increase in the criterion against derailment in the quasi-static riding conditions is valid for both the DBI and DB II profiles.

Analyzing formulas (1) and (2) it can be found that the smaller the rim inclination angle $\gamma$ is, the more probability of rail vehicle derailment increases. Thus, with the wear of the flange ( in the direction of reducing the inclination angle), the derailment index $(\mathbf{Y} / \mathbf{Q})$ reduces.

As a result of this unsatisfactory operating experiences with a running surface profile of 1:40 and 1:20, DB II profile was developed, which was later called „worn profile." This profile was further developed by the
Istotne zmiany geometryczne, które zostały wprowadzone $\mathrm{w}$ tym profilu polegały na prowadzeniu:

$>$ dwóch powierzchni stożkowych tzn. bez promienia (od strony wewnętrznej) oraz 1:10 (od strony zewnętrznej),

$>$ zastosowanie wgłębienia (przejścia) pomiędzy powierzchnią toczną oraz obrzeżem za pomocą dwóch promieni $\mathbf{R}=\mathbf{1 5} \mathbf{~ m m}$ oraz $\mathbf{R}=\mathbf{2 5} \mathbf{~ m m}$,

$>$ wprowadzeniu kąta pochylenia obrzeża $\boldsymbol{\gamma}=\mathbf{7 0}^{\mathbf{0}}$, zamiast wcześniej stosowanego kąta $\gamma=60 .^{\circ}$

Była to pierwsza próba zbliżenia się do zastosowania takiego profilu, który powstaje w wyniku zużycia, ale dalej jest profilem dopasowanym do pary ciernej kołoszyna. Wprowadzenie kąta pochylenia obrzeża $\mathrm{z}$ $\boldsymbol{\gamma}=\mathbf{6 0}^{\circ}$ na $\boldsymbol{\gamma}=\mathbf{7 0}^{\circ}$ zmieniło na korzyść kryterium bezpieczeństwa przed wykolejeniem zgodnie z zależnościami:

$$
\begin{gathered}
\frac{\mathrm{Y}}{\mathrm{Q}}=\frac{\operatorname{tg} \gamma-\mu}{1+\mu \cdot \operatorname{tg} \gamma}=\frac{\operatorname{tg} 60^{\circ}-0,36}{1+0,36 \cdot \operatorname{tg} 60^{\circ}}=0,84 \\
\frac{\mathrm{Y}}{\mathrm{Q}}=\frac{\operatorname{tg} \gamma-\mu}{1+\mu \cdot \operatorname{tg} \gamma}=\frac{\operatorname{tg} 70^{\circ}-0,36}{1+0,36 \cdot \operatorname{tg} 70^{\circ}}=1,20
\end{gathered}
$$

Zwiększenie kryterium przed wykolejeniem $\mathrm{w}$ warunkach jazdy quasistatycznej obowiązuje zarówno dla profilu DBI oraz DB II.

Analizując wzory (1) oraz (2) można stwierdzić, że im mniejszy kąt pochylenia obrzeża $\gamma$, tym bardziej zwiększa się prawdopodobieństwo wykolejenia pojazdu szynowego. Tak więc wraz ze zużyciem obrzeża w kierunku pomniejszenia jego kąta pochylenia obrzeża, działa negatywnie na bezpieczeństwo jazdy, a ściślej zmniejsza wskaźnik wykolejenia (Y/Q).

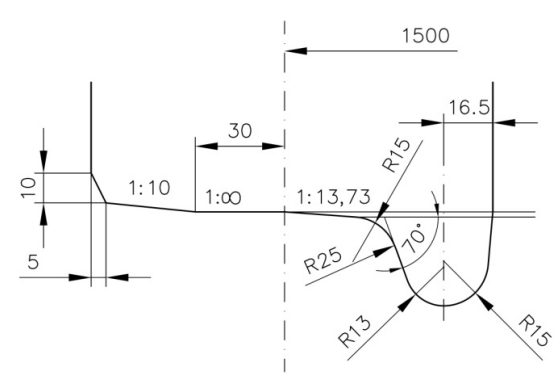

Rys.3. Zarys zewnętrzny wieńca koła o pochyleniu powierzchni tocznej 1: $\propto$ oraz 1:10 wg Heumanna i Lottera (tzw. profil DB I) wg [3]

Fig.3. The outer outline of the wheel rim with a running surface inclination of $1: \propto$ and 1:10 according to Heumann and Lotter (socalled DB I profile) according to [3]

W wyniku tych nie zadawalających doświadczeń eksploatacyjnych z profilem powierzchni tocznej 1:40 i 1:20, opracowano profil DB II, który później został nazwany „profilem zużytym.” Profil ten został dalej rozwijany przez kolej niemiecką DB oraz inne europejskie zarządy kolejowe i przyjął nazwę profilem UIC-ORE S1002. Profil ten został przedstawiony w 
German railway DB and other European railway authorities and it was called the UIC-ORE S1002 profile. This profile was presented in the UIC 510-2 leaflet [17] and in PN-EN 13715+A1:2011 [14] (Fig.4) as a standard one.

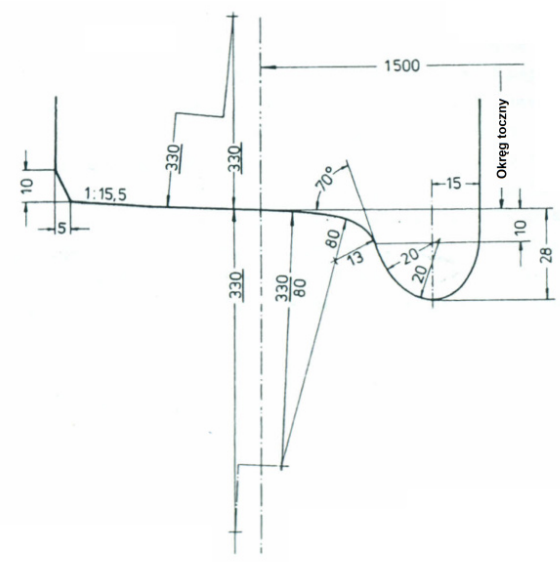

Rys.4. Zarys zewnętrzny wieńca koła DBII (profil DB II) wg [3] Fig.4. The outer outline of DBII wheel rim (DB II profile) according to [3]

\section{Wear of the wheel rim outline (profile)}

The rim wear of wheel can be divided into the following types:

$>$ profile wear,

$>$ damage to the running surface,

$>$ permanent deformation (rolling),

$>$ non-roudness (non-periodic, e.g. flat places, single delaminations with periodic character e.g. polygonization or waviness of the wheel).

Profile wear always occurs and therefore overlaps with other types of wear. Profile wear can be divided into running surface wear and rim wear. This wear as a continuous loss of material (in macroscopic form) is defined in the literature as "natural wear." [1]. The definition of the frictional wear rule can be adopted on the basis of the so-called friction work hypothesis.

To determine the volume of wear of the wheel rim material, the following relation can be used:

$$
\mathrm{V}_{\mathrm{V}}=\mathrm{k} \cdot \mathrm{W}_{\mathrm{R}}
$$

$\mathrm{V}_{\mathrm{V}^{-}}$objętość zużytego materiału $\left[\mathrm{m}^{3}\right] /$ volume of worn material $\left[\mathrm{m}^{3}\right]$,

k- współczynnik zużycia $\left[\mathrm{m}^{3} / \mathrm{J}\right] /$ worn coefficient $\left[\mathrm{m}^{3} / \mathrm{J}\right]$,

$\mathrm{W}_{\mathrm{R}}$ - praca tarcia $[\mathrm{J}] /$ friction work $[\mathrm{J}]$.

The relation (3) describes the so-called "friction work" hypothesis, the main assumption of which is that the volume of wear increases linearly with increasing the friction work.

From the carried out research and development works, it was found that the $\mathbf{A}_{\mathbf{R E F}}$ friction surface remains unchanged, but the height of wear $\mathbf{h}$ changes. Therefore, the relation (3) takes the form: karcie UIC 510-2 [17] oraz w PN-EN 13715+ A1:2011 [14] (rys.4) jako standardowy.

\section{Zużycie zarysu wieńca (profilu) koła}

Zużycie wieńca koła można podzielić na następujące rodzaje:

$>$ zużycie profilu,

$>$ uszkodzenia na powierzchni tocznej,

$>$ deformacje o charakterze trwałym (rozwalcowanie),

> nieokrągłości (nie mające charakteru okresowego np. płaskie miejsca, pojedyncze rozwarstwienia, mające charakter okresowy np. poligonizacja lub falistość koła).

Zużycie profilu występuje zawsze, a zatem nakłada się $\mathrm{z}$ innymi rodzajami zużycia. Zużycie profilu, można podzielić na zużycie powierzchni tocznej oraz zużycie obrzeża. Zużycie to jako ciagła utrata materiału (w formie makroskopowej), jest określana $\mathrm{w}$ literaturze jako „zużycie naturalne.” [1]. Określenie reguły zużycia ciernego można przyjąć na podstawie tzw. hipotezy pracy ciernej.

Aby określić objętość zużycia materiału wieńca koła można posłużyć się następującą zależnością:

$$
\mathrm{V}_{\mathrm{V}}=\mathrm{k} \cdot \mathrm{W}_{\mathrm{R}}
$$

Zależność (3) opisuje tzw. hipotezę „pracy ciernej”, której głównym założeniem jest to, że objętość zużycia rośnie liniowo wraz ze wzrostem pracy ciernej.

$Z$ przeprowadzonych prac badawczo-rozwojowych stwierdzono, że powierzchnia cierna $\mathbf{A}_{\mathbf{R E F}}$ pozostaje niezmienna, natomiast zmienia się wysokość zużycia h. W związku z tym zależność (3) przyjmuje postać:

$$
\mathrm{V}_{\mathrm{V}}=\mathrm{h} \cdot \mathrm{dA} \mathrm{A}_{\mathrm{REF}}
$$

Wykorzystując zależność (3) wzór (4) przyjmuje postać:

$$
\mathrm{h}=\mathrm{k} \cdot \frac{\mathrm{W}_{\mathrm{R}}}{\mathrm{dA}_{\mathrm{REF}}}
$$

Jeśli przyjąć zależność z rys.5, że powierzchnia ubytku materiału powierzchni tocznej koła o promieniu $\mathbf{R}_{(\mathbf{R})}$ wskutek zużycia wynosi $\mathbf{A}_{\mathbf{R E F}}=\mathbf{2} \times \boldsymbol{\Omega} \times \mathbf{R}_{\mathbf{R}}(\mathbf{y}) \times \mathbf{d} \mathbf{y}_{\mathbf{R}}$, to wówczas zależność (5) przyjmuje postać następującą:

$$
\mathrm{h}(\mathrm{y})=\mathrm{k} \cdot \frac{\mathrm{W}_{\mathrm{R}}(\mathrm{y})}{2 \cdot \pi \cdot \mathrm{R}_{\mathrm{R}} \cdot \mathrm{dy}_{\mathrm{R}}}
$$

Eksperymenty laboratoryjne pokazują ogólnie, że współczynnik zużycia $\mathbf{k}$ nie przyjmuje wartości stałej przy równym stanie tarcia.

Wartość charakteryzuje intensywność pracy tarcia, co jest pokazane na rys.6 i ma bezpośredni związek na intensywność zużycia:

$>$ jeśli współczynnik $\quad \mathbf{P}_{\mathrm{R}} / \mathbf{A}<\quad \mathbf{4} \times \mathbf{1 0}^{6} \quad \mathrm{~W} / \mathbf{m}^{2}=\mathbf{4}$ $\mathbf{W} / \mathbf{m m}^{2}$, to wówczas występuje tzw. „łagodne zużycie", 


$$
\mathrm{V}_{\mathrm{V}}=\mathrm{h} \cdot \mathrm{dA} \mathrm{REF}_{\mathrm{R}}
$$

where:

$\mathrm{A}_{\mathrm{REF}}$-powierzchnia zużycia $\left[\mathrm{m}^{2}\right] /$ wear surface $\left[\mathrm{m}^{2}\right]$, h- wysokość zużycia [m]/ wear height [m].

Using the relation (3) the formula (4) takes the form:

$$
\mathrm{h}=\mathrm{k} \cdot \frac{\mathrm{W}_{\mathrm{R}}}{\mathrm{dA}_{\mathrm{REF}}}
$$

If we assume the relation from Fig. 5 that the surface of the material loss of the running surface of a wheel with radius $\mathbf{R}_{(\mathbf{R})}$ due to wear is $\mathbf{A}_{\mathbf{R E F}}=\mathbf{2} \times \boldsymbol{\pi} \times \mathbf{R}_{\mathbf{R}}(\mathbf{y}) \times \mathbf{d} \mathbf{y}_{\mathbf{R}}$, then the relation (5) takes the following form:

$$
\mathrm{h}(\mathrm{y})=\mathrm{k} \cdot \frac{\mathrm{W}_{\mathrm{R}}(\mathrm{y})}{2 \cdot \pi \cdot \mathrm{R}_{\mathrm{R}} \cdot \mathrm{dy}_{\mathrm{R}}}
$$

where:

$\mathrm{R}_{\mathrm{R}}$ - promień toczny koła $[\mathrm{m}] /$ rolling radius of wheel [m],

$\mathrm{dy}_{\mathrm{R}}$ - przyrost współrzędnej odciętych na

powierzchni tocznej koła [m] (rys.5)/increase of abscissa coordinate on the running surface of wheel [m] (Fig.5).

Laboratory experiments generally show that the wear coefficient $\mathbf{k}$ does not take a constant value at an equal state of friction.

The value characterizes the work intensity of friction, which is shown in Fig. 6 and it has a direct relation to the wear intensity:

$>$ if coefficient $P_{R} / A<4 \times 10^{6} \mathrm{~W} / \mathrm{m}^{2}=4 \mathrm{~W} / \mathrm{mm}^{2}$, then there is the so-called ,mild wear",

$>$ if coefficient $P_{R} / A>4 \times 10^{6} \mathrm{~W} / \mathrm{m}^{2}=4 \mathrm{~W} / \mathrm{mm}^{2}$, then there is the so-called, ,violent wear" or "heavy wear."

"Mild wear" in the wheel-rail system occurs when the phenomenon of tripoxidation is dominant, while with "violent wear" is accompanied by the phenomenon of adhesion. Therefore, the transition from ,mild wear" to „rapid wear" is accompanied by a change in the wear mechanisms. It can be assumed that in the case of " catastrophic wear" there is a phenomenon of abrasion. It is assumed that within the existing regimes, i.e. mild wear and violent wear, the coefficient $\mathrm{k}$ has a constant value.

The wear of a monoblock wheel (including for the most frequently met wheel diameter) is divided into two stages:

$>$ wheel wear until the last permissible reprofiling,

$>$ wheel wear after the last until reaching the limit dimensions of wheel.

As it can be seen from Fig. 5 the wear of the wheel is not equal in terms of intensity on the entire running surface.

The wear of a monoblock wheel (including for a monoblock wheel with the most frequently met diameter of $\phi 920 \mathrm{~mm}$ ) is divided into two stages:
$>$ jeśli współczynnik $\quad \mathbf{P}_{\mathrm{R}} / \mathbf{A}>\mathbf{4} \times \mathbf{1 0}^{\mathbf{6}} \quad \mathbf{W} / \mathbf{m}^{2}=\mathbf{4}$ $\mathbf{W} / \mathbf{m m}^{2}$, to wówczas występuje tzw. ,gwałtowne zużycie lub ,intensywne zużycie.”

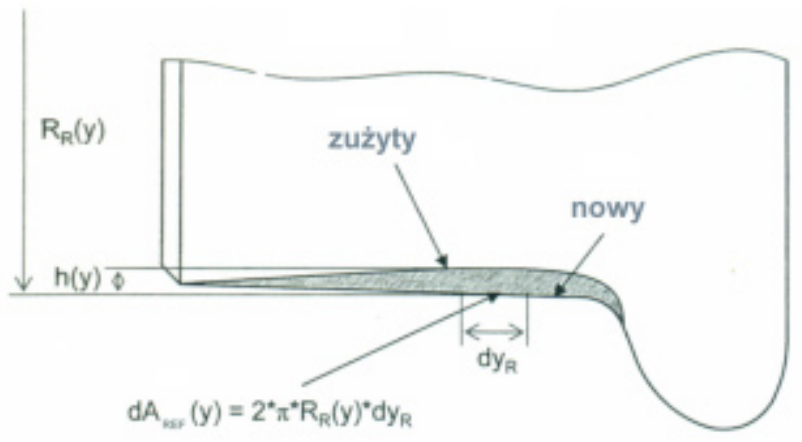

Rys.5. Wysokość zużycia h(y) i powierzchnia referencyjna (odniesienia) $\mathrm{d}_{\mathrm{REF}}$ oraz promień $\mathrm{R}_{\mathrm{R}}(\mathrm{y})$ na powierzchni tocznej koła kolejowego

Fig.5. Wear height $h(y)$ and reference surface $\mathrm{dA}_{\mathrm{REF}}$ and radius $R_{R}(y)$ on the running surface of a railway wheel

\section{Legenda/Legend:}

$d A_{R E F^{-}}$przyrost referencyjnej powierzchni zużycia kołoszyna/increase of the reference surface of wheel-rail wear h(y)- gtębokość zużycia zależna od wspótrzędnej ,y”/depth of wear depending on the „, $y$ " coordinate

$R_{R}(y)$-promien kota/ wheel radius.

„Łagodne zużycie” w układzie koło-szyna występuje wtedy, gdy dominujące jest zjawisko trybooksydacji, podczas gdy przy „gwałtownemu zużyciu” towarzyszy zjawisko adhezji. Dlatego też podczas przejścia z „łagodnego zużycia” do „gwałtownego zużycia” towarzyszy zmiana mechanizmów zużycia. Można wyjść z założenia, że w przypadku „katastrofalnego zużycia” występuje zjawisko abrazji. Zakłada się, że w ramach występujących reżimów tzn. zużycia o charakterze łagodnym oraz zużyciu o charakterze gwałtownym współczynnik $\mathbf{k}$ wykazuje stałą wartość.

Zużycie koła monoblokowego (w tym dla najczęściej spotykanej średnicy koła) dzieli się na dwa etapy:

$>$ zużycie koła do ostatniej dopuszczalnej reprofilacji,

$>$ zużycie koła po ostatniej aż do osiągnięcia wymiarów kresowych koła.

Jak widać z rys.5 zużycie koła nie jest równe pod względem intensywności na całej powierzchni tocznej.

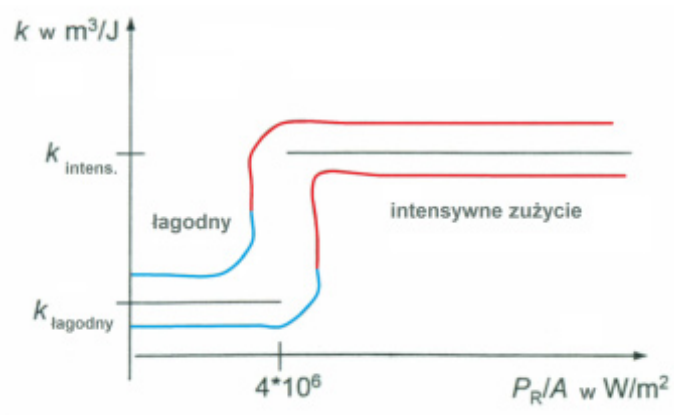

Rys.6. Współczynnik , ,k” w zależności od wskaźnika $\mathbf{P}_{\mathbf{R}} / \mathbf{A}$ w $\mathrm{W} / \mathrm{m}^{2}$ (reguła zużycia wg hipotezy pracy tarcia)

Fig.6. Coefficient ,, $\mathbf{k}$ ” in dependence on $\mathbf{P}_{\mathbf{R}} / \mathbf{A}$ index in $\mathrm{W} / \mathrm{m}^{2}$ (wear rule according to the friction work hypothesis) 
$>$ wheel wear until the last permissible reprofiling,

$>$ wheel wear until the wear groove disappears; in this case both wheels should be rolled from the axle and new wheels should be rolled onto it.

In the first standard wheel with a nominal rolling diameter, the wear of the wheel until the last allowable „reprofiling” is $25 \mathrm{~mm}$ on the radius, and until reaching the limit dimension is $4 \div 6 \mathrm{~mm}$ (i.e. $29 \div 31$ $\mathrm{mm}$ ). Later, as far as necessary to improve the competitiveness of rail transport on the transport market, the consumption reserve was increased even to $40 \mathrm{~mm}$ (until the last rolling) and an additional 5 $\mathrm{mm}$ after the last rolling. Such a possibility appeared in bogies of freight wagons after using the brake block insert „K”. In the case of increasing the reserve for wear to the above-mentioned values, in order to avoid exceeding the reference profile of the kinematic gauge by the sprung parts, the wear of the wheels of the wheelset should be compensated by inserting adjusting washers, preferably in the fastening place of the primary suspension coil springs. These washers must be removed after replacing worn wheels of wheelsets with new ones.

\section{CONCLUSIONS}

1. The issue of wheel wear of wheelsets is very complex and depends on many factors. The search for new materials for wheels by various railway institutions will still be valid, and the PN-EN 13262+A2:2011 standard [13] will be updated with time. This issue should always be related to the fact that the second element of the friction pair is the rail. The service life of the rails is very important here and their replacement is becoming more and more expensive. Therefore, the rails are made of steel with higher strength and hardness properties.

2. The important element to increase the life of wheel is certainly the quality of the track. Hence, it can be said that the introduction of new types of repairs, that is "on-time"" repairs and repairs based on the forecast of occurring damage based on the collected data is a great progress in the range of extending the service life of both the vehicle and the railway infrastructure.

3. Wheel wear is a very complex and complicated process. This issue requires the detailed analysis. Simplifying, it can be concluded that the smaller wheel-rail or in general track-vehicle system interaction, the lower wear of the wheels should be.
Zużycie koła monoblokowego (w tym dla koła monoblokowego o najczęściej spotykanej średnicy $\phi 920$ $\mathrm{mm})$ dzieli się na dwa etapy:

$>$ zużycie koła do ostatniej dopuszczalnej reprofilacji,

> zużycie koła aż do zniknięcia rowka zużyciowego; w tym przypadku należy wykonać stłoczenia obydwu kół z osi oraz wtłoczenie nowych kół.

W pierwszym kole standardowym o nominalnej średnicy tocznej zużycie koła do ostatniej dopuszczalnej „reprofilacji” wynosi $25 \mathrm{~mm}$ na promieniu, natomiast aż do osiagnięcia wymiaru kresowego wynosi $4 \div 6 \mathrm{~mm}$

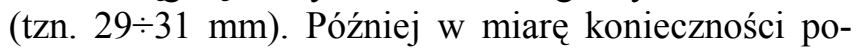
lepszenia konkurencyjności transportu kolejowego na rynku przewozowym zapas zużycia zwiększono nawet do $40 \mathrm{~mm}$ (do ostatniego przetoczenia) oraz dodatkowo $5 \mathrm{~mm}$ po ostatnim przetoczeniu. Możliwość taka pojawiła się $\mathrm{w}$ wózkach wagonów towarowych po zastosowaniu wstawki typu „K”. W przypadku zwiększenia zapasu na zużycie do ww. wartości, aby uniknąć przekroczenia zarysu odniesienia skrajni kinematycznej przez części usprężynowane, należy dokonać kompensacji zużycia kół zestawu kołowego przez wstawienie podkładek regulujących, najlepiej w miejsce osadcze sprężyn śrubowych usprężynowania pierwszego stopnia. Podkładki te muszą być zdjęte po wymianie zużytych kół zestawów kołowych na nowe.

\section{WNIOSKI}

1. Problematyka zużycia kół zestawów kołowych jest bardzo złożona i zależy od wielu czynników. Poszukiwanie nowych materiałów na koła przez różne instytucje zajmujące się kolejnictwem będzie wciąż aktualne, a norma PN-EN 13262+A2:2011 [13] będzie $z$ czasem aktualizowana. Zagadnienie to należy zawsze wiązać $\mathrm{z}$ faktem, że drugim elementem pary ciernej jest szyna. Żywotność szyn kolejowych jest tutaj bardzo istotna, a ich wymiana jest coraz bardziej kosztowna. Dlatego też szyny kolejowe są wykonywane ze stali o wyższych własnościach wytrzymałościowych oraz twardości.

2. Istotnym elementem, mającym na celu zwiększenie żywotności koła jest na pewno jakość toru. Stąd można powiedzieć, że wprowadzanie nowych rodzajów napraw czyli napraw typu „on-time” oraz napraw opartych na prognozie występujących uszkodzeń w oparciu o zebrane dane jest dużym postępem w zakresie wydłużenia żywotności, zarówno pojazdu, jak i infrastruktury kolejowej.

3. Zużycie koła jest procesem bardzo złożonym i skomplikowanym. Zagadnienie to wymaga szczegółowej analizy. Upraszczając można wyciąnnąć wniosek, że im mniejsze oddziaływanie w układzie koło-szyna lub ogólnie tor-pojazd, tym zużycie kół powinno być mniejsze. 


\section{BLIOGRAPHY / BIBLIOGRAFIA}

[1] Kämpfer B., Semrad F., Six K. Friedl K. Verschleiß- und Schädigungserscheinungen an Schienenfahrzeugrädern. ZEVrail Glassers Annalen Nr. 132 .2008

[2] Kik W., Mensen R., Moelle D. Kräfte und Verschleiß in der Wendeschleife und im Abzweig einer Weiche. Eisenbahningenieur. Nr. 4/2003

[3] Krugmann H.L.: Lauf der Schienenfahrzeuge im Gleis. Eine Einführung. R. Oldenburg Verlag München. Wiedeń 1982

[4] Sobaś M.: Zawieszenia i układy biegowe wagonów towarowych. Poznań 2014.

[5] Sobaś M.: Wpływ omaźnicowych zestawów kołowych na bezpieczeństwo eksploatacyjne wagonów towarowych. Pojazdy Szynowe nr 4/2016.

[6] Sobaś M.: Zastosowanie uszczelnień filcowych we współczesnych węzłach układów biegowych pojazdów szynowych. Pojazdy Szynowe nr 1/2018.

[7] Sobaś M.: Stan toru w świetle obowiqzujacych przepisów, a bezpieczeństwo jazdy wagonów towarowych w wózkach standardowych. Pojazdy Szynowe nr 3/2018

[8] Sobaś M.: Wytyczne do określenia nośności osi zestawów kołowych wagonów towarowych z czopem o wymiarach Ø120×179 mm. Pojazdy Szynowe nr 2/2019

[9] Sobaś M.: Analityczne określenie nośności osi zestawów kołowych wagonów towarowych. Pojazdy Szynowe $n r 3 / 2019$

[10] Sobaś M.: Określenie ugięcia osi z czopem o wymiarach Ø 120×179 mm zestawów kołowych wagonów towarowych. Pojazdy Szynowe nr 4/2019

[11] PN-EN 12060+A1:2011. Kolejnictwo. Zestawy kołowe i wózki. Zestawy kołowe. Wymagania dotyczqce wyrobu.

[12] PN-EN 12061+A1:2011. Kolejnictwo. Zestawy kołowe i wózki. Osie. Wymagania dotyczqce wyrobu.

[13] PN-EN 13262+A2:2011. Kolejnictwo. Zestawy kołowe i wózki. Koła. Wymagania dotyczace wyrobu.

[14] PN-EN 13715+A1:2011. Kolejnictwo. Zestawy kołowe i wózki. Koła. Zewnętrzne zarysy wieńców kót.

[15] PN-EN 14363:2016. Kolejnictwo. Badania i symulacje modelowe właściwości dynamicznych pojazdów szynowych przed dopuszczeniem do ruchu. Badania właściwości biegowych i próby stacjonarne.

[16] Karta UIC 510-1. Wagony towarowe. Układ biegowy. Normalizacja. 9.te wydanie z 1.01.78. 14. zmian od 1.01 .80 do 1.01 .97

[17] Karta UIC 510-2. Pojazdy doczepne. Warunki dla stosowania kót o różnych średnicach w układach biegowych różnego typu. 4.te wydanie. Październik 2002 -kwiecień 2004.

[18] Karta UIC 515-0. Wagony pasażerskie. Wózki-Układy biegowe.2.gie wydanie, kwiecień 2001

[19] Karta UIC 519. Metoda określenia stożkowatości ekwiwalentnej. 1. wydanie grudzień 2004.

[20] Karta UIC 832. Warunki techniczne dostawy wstawek klocków hamulcowych z żeliwa fosforowego dla pojazdów trakcyjnych i wagonów. Sierpień 2015. 